Int. J. Electrochem. Sci., 12 (2017) $710-725$

International Journal of

ELECTROCHEMICAL

SCIENCE

WWW.electrochemsci.org

\title{
The Electrocatalytic Activity of Pyrazolyl-thioimidazolyl borate- based Zinc(II) Complexes Towards the Hydrolysis of Tris( $p$ - nitrophenyl)phosphate
}

\author{
Gaber A. M. Mersal ${ }^{1,2, *}$, Mohamed M. Ibrahim ${ }^{1,3}$, Sahar Fadllalh ${ }^{1,4}$, Hamdy S. El-Sheshtawy ${ }^{3}$, Mona \\ M. B. Al-Malki ${ }^{l}$ \\ ${ }^{1}$ Chemistry Department, Faculty of Science, Taif University, 888 Taif, KSA. \\ ${ }^{2}$ Chemistry Department, Faculty of Science, South Valley University, Qena, Egypt \\ ${ }^{3}$ Chemistry Department, Faculty of Science, Kafr El-Sheikh University, Kafr El-Sheikh 33516, Egypt. \\ ${ }^{4}$ Chemistry Department, Faculty of Science, Cairo University, Egypt \\ "E-mail: gamersal@yahoo.com
}

doi: $10.20964 / 2017.01 .50$

Received: 13 August 2016 / Accepted: 24 October 2016 / Published: 12 December 2016

Two zinc(II) compounds of pyrazolyl-thioimidazolyl containing ligands of the types $\left[\mathrm{HB}\left(\mathrm{Pz}^{\mathrm{MePh}}\right)\left(\mathrm{Tt}^{\mathrm{OMe}}\right)_{2} \mathrm{ZnCl}\right] \mathbf{1}$ and $\left[\mathrm{HB}\left(\mathrm{Pz}^{\mathrm{MePh}}\right)\left(\mathrm{Tt}^{\mathrm{OMe}}\right)_{2} \mathrm{ZnClO}_{4}\right] 2$ were synthesized and characterized as new electrocatalysts for the hydrolysis of the phosphotriester tris(4-nitrophenyl)phosphate (TPP). Their structures were characterized spectroscopically by infrared and ${ }^{1} \mathrm{H}_{-}{ }^{13} \mathrm{C}$ NMR spectroscopies as well as elemental analysis and thermal analysis. The zinc atoms adopt distorted tetrahedral geometry with coordination chromophores $\mathrm{ZnS}_{2} \mathrm{NCl}$ and $\mathrm{ZnS}_{2} \mathrm{NO}$ for complexes $\mathbf{1}$ and 2, respectively. The electrochemical behavior of the obtained zinc complexes-modified carbon paste electrode (Zn-CPE) has been studied by cyclic voltammetry. The $\mathrm{Zn}-\mathrm{CPE}$ shows good electrocatalytic activities toward the hydrolysis of TPP, generates the oxidized $p$-nitrophenol at the surface of CPE. Several parameters were investigated to evaluate the performance of the biomimetic sensor obtained after the incorporation of zinc(II) complexes $\mathbf{1}$ and $\mathbf{2}$ in a carbon paste electrodes.

Keywords: Pyrazolyl-Thioimidazolyl borate containing ligand Biomimetic sensors; Electrocatalytic; DFT calculations.

\section{$\underline{\text { FULL TEXT }}$}

(C) 2017 The Authors. Published by ESG (www.electrochemsci.org). This article is an open access article distributed under the terms and conditions of the Creative Commons Attribution license (http://creativecommons.org/licenses/by/4.0/). 